\title{
DENSITAS ENERGI MAKANAN DAN LINGKAR PINGGANG SEBAGAI FAKTOR RISIKO PENINGKATAN KADAR C-REACTIVE PROTEIN (CRP) PADA REMAJA OBESITAS DENGAN SINDROM METABOLIK
}

\author{
Santi Mayasari, Muhammad Sulchan ${ }^{*}$ \\ Program Studi Ilmu Gizi Fakultas Kedokteran Universitas Diponegoro \\ Jl.Dr.Sutomo No.18, Semarang, Telp (024) 8453708, Email : gizifk@undip.ac.id
}

\begin{abstract}
Background: Prevalence of metabolic syndrome is increasing due to incerased prevalence of obesity in adolescents. Adolescents prefer consume food with high densityenergy. Waist circumference is a risk factor for metabolic syndrome showed mild inflamation. Levels of c-reactive protein (CRP) is increased by presence of inflamation. Dietary energy density and waist circumference are risk factors for increased levels of CRP. The purpose of this study is to define risk factors of dietary energy density and waist circumference to increased levels of CRP.

Method: The study was carried out in SMA Negeri 2 Semarang. A cross sectional study design with the amount of subjects are 38. Metabolic syndrome data obtained by anthropometric, blood pressure, and lipid profile from venous bood sample. The prevalence of metabolic syndrome is defined as the presence of $\geq 3$ of the following risk factors: triglyceride $\geq 110 \mathrm{mg} / \mathrm{dl}, \mathrm{HDL} \leq 40 \mathrm{mg} / \mathrm{dl}$, fasting glucose level $\geq 110 \mathrm{mg} / \mathrm{dl}$, and blood pressure or waist cirmcumference at or above the 90th percentile. Dietary energy density data obtained by interview using a food frequency questionaire.

Results: The prevalence of obesity was $7.9 \%$. The prevalence of metabolic syndrome in obese adolescents $15.2 \%$. Found a significant relationship between energy density ( $r: 0.506, p: 0.004)$ and waist circumference. There is no relationship between energy $(r: 0,240 ; p: 0,430)$ and waist circumference $(r: 0,433 ; p: 0,139)$ with increased levels of CRP.
\end{abstract}

Conclusion: In this study waist circumference proved to be a risk factor to increased levels of CRP. Dietary energy density not proved as a risk factor to increased levels of CRP.

Keywords: obesity, metabolic syndrome, dietary energy density, waist circumference, $C$-reactive protein $(C R P)$

\section{ABSTRAK}

Latar Belakang: Prevalensi sindrom metabolik pada remaja semakin meningkat karena peningkatan prevalensi obesitas pada remaja. Remaja lebih memilih mengkonsumsi makanan dengan densitas energi tinggi. Lingkar pinggang merupakan salah satu faktor risiko sindrom metabolik menunjukkan adanya inflamasi ringan. Kadar $C$ Reactive Protein (CRP) meningkat dengan adanya inflamasi. Densitas energi makanan dan lingkar pinggang merupakan faktor risiko peningkatan kadar CRP. Tujuan penelitian ini adalah untuk mengetahui besarnya risiko faktor densitas energi makanan dan lingkar pinggang terhadap peningkatan kadar CRP.

Metode: Penelitian dilakukan di SMA Negeri 2 Semarang. Desain penelitian cross sectional dengan jumlah subyek 38. Data sindrom metabolik diperoleh dengan melakukan pengukuran antropometri, tekanan darah dan pemeriksaan lipid darah. Sindrom metabolik dinyatakan apabila memenuhi $\geq 3$ kriteria sebagai berikut: trigliserid $\geq 110 \mathrm{mg} / \mathrm{dl}, \mathrm{HDL} \leq 40 \mathrm{mg} / \mathrm{dl}$, glukosa darah puasa $\geq 110 \mathrm{mg} / \mathrm{dl}$, tekanan darah dan atau lingkar pinggang $\geq$ persentil ke-90. Data densitas energi diperoleh dengan wawancara menggunakan food frequency questionaire.

Hasil: Prevalensi obesitas sebesar 7,9\%. Prevalensi sindrom metabolik pada remaja obesitas 15,2\%. Ditemukan hubungan bermakna antara densitas energi ( $r$ : 0,506; p: 0,004)dengan lingkar pinggang. Tidak ada hubungan antara densitas energi ( $r: 0,240 ; p: 0,430)$ dan lingkar pinggang $(r: 0,433 ; p: 0,139)$ dengan peningkatan kadar CRP.

Simpulan: Dalam penelitian ini lingkar pinggang terbukti merupakan faktor risiko terhadap peningkatan kadar CRP. Densitas energi makanan tidak terbukti sebagai faktor risiko terhadap peningkatan kadar CRP.

Kata Kunci: obesitas, sindrom metabolik, densitas energi makanan, lingkar pinggang, C-Reactive Protein (CRP)

\section{PENDAHULUAN}

Sindrom

kesehatan, berdasarkan kriteria NCEP-ATP III, prevalensi di seluruh dunia berkisar antara 15$30 \%,{ }^{2}$ pada populasi Asia berkisar antara $10-15 \%$. Sedangkan di Indonesia, pada tahun 2004 prevalensinya mencapai $24,4 \%$ (Himpunan Studi Obesitas Indonesia) dan di DKI Jakarta pada tahun 2006 menunjukkan prevalensi sindrom metabolik 
yang lebih besar yaitu sebesar $28,4 \% .^{3}$ National Health and Nutrition Examination Survey III (NHANES III) tahun 1988-1994 menunjukkan bahwa sindrom metabolik mencapai $4,2 \%$ pada remaja usia $12-19$ tahun dan $28,7 \%$ pada remaja obesitas. $^{4}$

Prevalensi sindrom metabolik meningkat dengan meningkatnya usia dan peningkatan angka kejadian obesitas. ${ }^{5}$ Obesitas pada remaja dan dewasa muda mengalami peningkatan dalam kurun waktu lima tahun terakhir, yaitu dari 10,9\% menjadi 22,1\%. ${ }^{6} \quad$ Remaja cenderung mengkonsumsi makanan dengan densitas energi tinggi seperti fast food, kentang goreng, ayam goreng. Makanan padat energi adalah makanan dengan densitas energi yang tinggi, biasanya tinggi kadungan karbohidrat sederhana, gula dan lemak, maka cenderung lebih lezat dan gurih sehingga lebih disukai oleh remaja. Berdasarkan RISKESDAS tahun 2007 di Indonesia, unhealthy food seperti makanan dengan penyedap, manis dan berlemak banyak dikonsumsi oleh anak usia 12-15 tahun. ${ }^{8}$ Asupan makan pada remaja yang tinggi energi berpotensial menimbulkan obesitas, karena bila dikonsumsi lebih dari yang jumlah yang dibutuhkan akan disimpan didalam tubuh sebagai sel-sel lemak. ${ }^{9}$ Keseimbangan energi positif yang terjadi karena asupan makanan yang berlebih terutama makanan tinggi kalori dan sumber karbohidrat dapat menyebabkan akumulasi lemak di jaringan adiposa abdominal. Remaja yang mengalami obesitas akan cenderung mengalami obesitas saat dewasa serta dapat meningkatkan risiko terjadinya sindrom metabolik seperti hipertensi, diabetes melitus tipe 2, penyakit jantung koroner dan gangguan perkembangan emosional.

Obesitas terbagi menjadi obesitas general dan obesitas sentral. Lingkar pinggang adalah ukuran antropometri yang digunakan untuk menentukan obesitas sentral, kriteria untuk Asia Pasifik yaitu $\geq 90 \mathrm{~cm}$ untuk pria dan $\geq 80 \mathrm{~cm}$ untuk wanita. ${ }^{10}$ Penimbunan lemak dalam perut yang dikenal dengan obesitas sentral atau obesitas viseral lebih berkaitan dengan kejadian sindrom metabolik dan penyakit jantung koroner. Obesitas sentral dikenal sebagai tanda yang dapat menunjukkan terjadinya sindrom metabolik. Lingkar pinggang yang besar berkaitan dengan nilai $C$-Reaktif Protein (CRP) yang tinggi pada remaja. Lingkar pinggang yang besar dapat menunjukkan adanya inflamasi ringan. Jaringan lemak viseral dapat meningkatkan kadar proinflamatori sitokin untuk memproduksi inflamatori sitokin. ${ }^{11}$ Produksi CRP induksi oleh Interleukin-6 (IL-6) dan diregulasi oleh inflamatori sitokin. Nilai CRP yang tinggi dapat menunjukkan adanya induksi sitokin yang menggambarkan proses proinflamasi. ${ }^{12}$ CRP merupakan biomarker dalam sirkulasi gangguan endothelial. Remaja yang mengalami obesitas memiliki konsentrasi CRP yang lebih tinggi daripada remaja dengan berat badan normal.

C-reactive protein (CRP) adalah suatu tanda sensitif untuk inflamasi sistemik dan diproduksi oleh hepar. ${ }^{5}$ Peningkatan serum CRP berkaitan dengan perubahan arterial awal pada anak dan remaja yang mengalami obesitas. ${ }^{13}$ Remaja yang mengalami obesitas memiliki konsentrasi CRP yang lebih tinggi daripada remaja dengan berat badan normal. Asupan makanan berkaitan dengan peningkatan kadar CRP dan gejala inflamasi. Variasi makanan yang dikonsumsi dapat mempengaruhi kadar CRP, konsumsi tinggi sayur dan buah dapat menurunkan kadar CRP. ${ }^{14}$ Sindrom metabolik sangat erat hubungannya dengan peningkatan risiko terhadap penyakit jantung koroner dan penyakit metabolik seperti diabetes mellitus tipe 2 dan aterosklerosis. ${ }^{15}$ Berdasarkan uraian diatas, densitas energi dan lingkar pinggang merupakan faktor risiko peningkatan kadar CRP pada remaja obesitas dengan sindrom metabolik. Tujuan dari penelitian ini adalah untuk menganalisis densitas energi dan lingkar pinggang sebagai faktor risiko peningkatan kadar CRP pada remaja obesitas dengan sindrom metabolik.

\section{METODE PENELITIAN}

Penelitian ini termasuk dalam ruang lingkup keilmuan gizi masyarakat menggunakan desain cross sectional. Pengambilan data meliputi dua tahap, yaitu pengambilan data awal dan pengambilan data lanjutan.

Populasi dalam penelitian ini adalah semua remaja usia 15-18 tahun di kota Semarang. Pengambilan data dan pemilihan sampel dengan melakukan skrining pengukuran berat badan, tinggi badan dan lingkar pinggang pada 835 siswa SMA Negeri 2 Semarang. Jumlah siswa yang memenuhi kriteria inklusi sebesar 47 siswa. Pengambilan data lanjut dilakukan pada 38 siswa sesuai dengan rumus untuk menghitung sampel minimal. Kriteria inklusi yang digunakan pada penelitian ini adalah remaja yang berusia 15-18 tahun, mengalami obesitas yang ditandai dengan Indeks Massa Tubuh (IMT) terhadap umur dan jenis kelamin $\geq$ persentil ke-95, mengalami obesitas sentral (lingkar 
pinggang $\geq$ persentil ke-90, yaitu $\geq 93 \mathrm{~cm}$ untuk laki-laki, $\geq 87 \mathrm{~cm}$ untuk perempuan). Kriteria eksklusi dalam penelitian ini adalah subyek mengundurkan diri, sakit, atau meninggal dunia saat penelitian berlangsung.

Variabel terikat dalam penelitian ini adalah kadar $C$-reactive protein (CRP), variabel bebasnya adalah densitas energi dan lingkar pinggang. Pengukuran antropometri dilakukan untuk menentukan status gizi subjek berdasarkan $B M I-$ for age percentile kemudian menentukan obesitas sentral. Berat badan diukur menggunakan timbangan digital dengan ketelitian $0,01 \mathrm{~kg}$, tinggi badan diukur menggunakan microtoise dengan ketelitian $0,1 \mathrm{~cm}$. Status gizi subjek dinyatakan normal jika BMI-for age percentile 5 sampai $<$ persentil ke-95 dan obesitas jika $\geq$ persentil ke-95. Lingkar pinggang diukur menggunakan pita meter dengan ukuran maksimal $150 \mathrm{~cm}$, subjek yang memiliki obesitas sentral jika lingkar pinggang $\geq$ persentil ke-90, yaitu untuk laki-laki sebesar $\geq 93$ $\mathrm{cm}$ dan untuk perempuan adalah $\geq 87 \mathrm{~cm}$. Tekanan darah diukur dengan metode tidak langsung (indirect method) dengan cara auskultasi.

Sindrom metabolik ditentukan jika subyek memenuhi $\geq 3$ faktor risiko dari sindrom metabolik berdasarkan National Cholesterol Education Program Adult Treatment Panel III (NCEP ATP III) untuk remaja: obesitas sentral (lingkar pinggang $\geq$ persentil ke- 90 , yaitu $\geq 93 \mathrm{~cm}$ untuk laki-laki, $\geq 87 \mathrm{~cm}$ untuk perempuan), hipertensi (tekanan darah sistolik dan/ atau diastolik zpersentil ke-90), kadar kolesterol HDL <40 $\mathrm{mg} / \mathrm{dL}$, kadar trigliserida $\geq 110 \mathrm{mg} / \mathrm{dL}$, dan kadar GDP $\geq 110 \mathrm{mg} / \mathrm{dL}$, sedangkan subyek dikatakan mengalami pra sindrom metabolik jika memenuhi $<3$ faktor risiko sindrom metabolik tersebut.

Densitas energi makanan adalah jumlah energi dalam berat tertentu dari makanan yang dihitung dengan cara membagi asupan energi total perhari dengan berat makanan total yang dikonsumsi diperoleh melalui wawancara secara langsung menggunakan metode Food Frequency
Questionnaire (FFQ) semi kuantitatif. Asupan makanan untuk laki-laki dinyatakan memiliki densitas energi yang normal jika densitas energi 1,53-2,08 kkal/g, dan dinyatakan memiliki densitas energi tinggi jika mencapai $>2,09 \mathrm{kkal} / \mathrm{g}$. Asupan makanan yang dikonsumsi dalam sehari memiliki densitas energi 1,45-1,98 $\mathrm{kkal} / \mathrm{g}$ dinyatakan memiliki densitas energi normal dan dinyatakan memiliki densitas energi tinggi jika mencapai $>1,99 \mathrm{kkal} / \mathrm{g}$ untuk perempuan. ${ }^{16}$

Kadar $C$-reactive protein (CRP) adalah suatu tanda sensitif untuk menggambarkan adanya inflamasi sistemik. Kadar CRP diukur menggunakan metode aglutinasi yang dilakukan di laboratorium klinik. Kadar CRP dinyatakan tinggi jika nilainya > $6 \mathrm{mg} / \mathrm{L}$. Kadar CRP dinyatakan normaljika nilainya $<6 \mathrm{mg} / \mathrm{L}$.

Pengolahan data menggunakan program komputer. Uji normalitas dilakukan untuk mengetahui kenormalan distribusi data dengan menggunakan uji Shapiro-Wilk. Uji hubungan Pearson dan Spearman dilakukan untuk menguji hubungan densitas energi dengan faktor risiko sindrom metabolik serta hubungan CRP dengan faktor risiko sindrom metabolik. Besar risiko densitas energi dan lingkar pinggang terhadap peningkatan kadar CRP dilakukan dengan menghitung nilai Rasio Prevalensi (RP).

\section{HASIL PENELITIAN \\ Karakteristik Subyek Penelitian}

Hasil skrining awal melibatkan 835 subyek yang berasal dari SMA Negeri 2 Semarang dengan melakukan pengukuran berat badan, tinggi badan, lingkar pinggang, dan tekanan darah. Hasil skrining menunjukkan bahwa $80(9,58 \%)$ subyek termasuk overweight, 66(7,9\%) subyek termasuk obesitas, $61(7,3 \%)$ subyek termasuk dalam obesitas sentral, dan 10(1,2\%) subyek termasuk dalam sindrom metabolik. $15,2 \%$ subyek termasuk dalam sindrom metabolik jika dilihat diantara subyek yang mengalami obesitas. Karakteristik subyek penelitian dapat dilihat pada tabel 1 .

Tabel 1. Usia, Status Gizi dan Faktor Risiko Sindrom Metabolik

\begin{tabular}{lll}
\hline Variabel & Sindrom Metabolik & \multicolumn{1}{c}{ Pra Sindrom Metabolik } \\
\hline Total & $(\mathbf{n = 1 0})$ & $(\mathbf{n}=\mathbf{3 7})$ \\
Usia (th) & $16,5(15-17)$ & $16(15-17)$ \\
IMT $\left(\mathrm{Kg} / \mathrm{m}^{2}\right)$ & $32,5(29.6-45,6)$ & $30,3(25,9-43,3)$ \\
Lingkar Pinggang (cm) & $105(97,5-120,3)$ & $93,5(87-134)$ \\
TD Sistolik (mmHg) & $130(120-140)$ & $110(100-140)$ \\
TD Diastolik (mmHg) & $70(70-80)$ & $70(70-80)$ \\
GDP (mg/dL) & $79,9 \pm 10,9$ & $82,2 \pm 6,2$ \\
Trigliserida (mg/dL) & $119(72-181)$ & $72(50-135$ \\
Kolesterol HDL (mg/dL) & $32,5(30-48)$ & $42(30-56)$ \\
\hline
\end{tabular}




\begin{tabular}{lll}
\hline Laki-laki & $(\mathbf{n}=\mathbf{1 0})$ & $\mathbf{( n = 1 8})$ \\
Usia $(\mathrm{th})$ & $16,5(15-17)$ & $16(15-17)$ \\
IMT $\left(\mathrm{Kg} / \mathrm{m}^{2}\right)$ & $32,6(29,6-45,6)$ & $30,3(25,9-43,3)$ \\
Lingkar Pinggang (cm) & $105,9 \pm 8,1$ & $101,4 \pm 10,3$ \\
TD Sistolik (mmHg) & $130(120-140)$ & $120(110-140)$ \\
TD Diastolik (mmHg) & $70(70-80)$ & $70(70-80)$ \\
GDP (mg/dL) & $79,9 \pm 10,9$ & $83,6 \pm 5,6$ \\
Trigliserida (mg/dL) & $117,2 \pm 32,5$ & $76,5 \pm 15,2$ \\
Kolesterol HDL (mg/dL) & $32,5(30-48)$ & $40(30-56)$ \\
\hline Perempuan & & $\mathbf{( n = 1 9 )}$ \\
Usia (th) & - & $16(15-17)$ \\
IMT (Kg/m $\left.{ }^{2}\right)$ & - & $31,4 \pm 2,8$ \\
Lingkar Pinggang (cm) & - & $90(87-114,4)$ \\
TD Sistolik (mmHg) & - & $110(100-120)$ \\
TD Diastolik (mmHg) & - & $70(70-70)$ \\
GDP (mg/dL) & - & $81 \pm 6,6$ \\
Trigliserida (mg/dL) & - & $51(50-135)$ \\
Kolesterol HDL (mg/dL) & - & $44,1 \pm 6,1$ \\
\hline
\end{tabular}

Catatan =IMT Indeks Massa Tubuh, LP Lingkar Pinggang, TDS Tekanan Darah Sistol, TDD Tekanan Darah Diastol, GDP Gula Darah Puasa, TG Trigliserida, HDL High Density Lipoprotein.

Tabel 1 menunjukkan karakteristik subyek meliputi usia, status gizi dan faktor risiko sindrom metabolik yang dibagi menurut jenis kelamin dan total subyek berdasarkan kelompok sindrom metabolik dan kelompok pra sindrom metabolik. Jumlah subyek yang mengalami sindrom metabolik adalah 10 siswa, yang mengalami pra sindrom metabolik adalah 37 siswa. Subyek lakilaki yang mengalami sindrom metabolik sebanyak 10 siswa, sedangkan yang mengalami pra sindrom metabolik sebanyak 18 siswa. Kelompok sindrom metabolik pada laki-laki memiliki nilai median lebih tinggi dari kelompok pra sindrom metabolik kecuali variabel tekanan darah diastolik dan kadar HDL.

Subyek perempuan pada penelitian ini hanya mengalami pra sindrom metabolik yaitu sebanyak 19 siswa. Pada perempuan nilai median tidak dapat dibandingkan antara masing-masing kelompok karena pada subyek perempuan hanya terdapat kelompok pra sindrom metabolik. Berdasarkan total subyek, nilai median kelompok sindrom metabolik lebih tinggi dari kelompok pra sindrom metabolik, kecuali variabel tekanan darah diastolik dan kolesterol HDL.

Tabel 2 menunjukkan obesitas sentral memiliki frekuensi tertinggi yaitu 38(100\%) siswa mempunyai lingkar pinggang yang sesuai dengan kriteria komponen sindrom metabolik berdasarkan kriteria NCEP ATP III. Batas lingkar pinggang pada laki-laki adalah $>93 \mathrm{~cm}$, sedangkan perempuan adalah $>87 \mathrm{~cm}$. Semua subjek memiliki lingkar pinggang yang sesuai dengan kriteria sindrom metabolik karena pengukuran lingkar pinggang termasuk dalam skrining awal untuk menentukan jumlah subjek. Siswa yang memiliki lingkar pinggang kurang dari cut off point tidak termasuk dalam subjek penelitian.

Tabel 2. Frekuensi Faktor Risiko Sindrom Metabolik

\begin{tabular}{lcccc}
\hline Komponen & $\begin{array}{c}\text { Sindrom Metabolik } \\
(\mathbf{n = 1 0})\end{array}$ & $\begin{array}{c}\text { Pra Sindrom } \\
\text { Metabolik (n=37) }\end{array}$ \\
\hline Total & 10 & $100 \%$ & 37 & $100 \%$ \\
LP (obesitas sentral) & 8 & $80 \%$ & 2 & $5,4 \%$ \\
TDS $\geq 122 \mathrm{mmHg}$ & 4 & $40 \%$ & 1 & $2,7 \%$ \\
TDD $\geq 77 \mathrm{mmHg}$ & - & - & - & - \\
GDP $\geq 100 \mathrm{mg} / \mathrm{dL}$ & 6 & $60 \%$ & 3 & $8,1 \%$ \\
Trigliserida $\geq 110 \mathrm{mg} / \mathrm{dL}$ & 9 & $90 \%$ & 13 & $35,1 \%$ \\
HDL $<40 \mathrm{mg} / \mathrm{dL}$ & & & & \\
& & & & \\
Laki-laki & 10 & $100 \%$ & 18 & $100 \%$ \\
LP $>93$ & 8 & $80 \%$ & 2 & $11,1 \%$ \\
TDS $\geq 122 \mathrm{mmHg}$ & 4 & $40 \%$ & 1 & $5,6 \%$ \\
TDD $\geq 77 \mathrm{mmHg}$ & - & - & - & -
\end{tabular}


Trigliserida $\geq 110 \mathrm{mg} / \mathrm{dL}$ $\mathrm{HDL}<40 \mathrm{mg} / \mathrm{dL}$

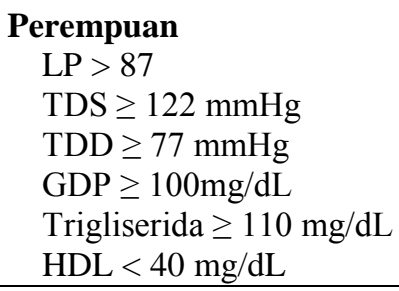

\begin{tabular}{|c|c|c|c|c|}
\hline \multirow{2}{*}{$\begin{array}{l}\text { Trigliserida } \geq 110 \mathrm{mg} / \mathrm{dL} \\
\mathrm{HDL}<40 \mathrm{mg} / \mathrm{dL}\end{array}$} & & $60 \%$ & - & - \\
\hline & & $90 \%$ & 9 & $50 \%$ \\
\hline \multicolumn{5}{|l|}{ Perempuan } \\
\hline \multicolumn{2}{|l|}{$\mathrm{LP}>87$} & - & 19 & $100 \%$ \\
\hline \multicolumn{2}{|l|}{$\mathrm{TDS} \geq 122 \mathrm{mmHg}$} & - & - & - \\
\hline \multicolumn{2}{|l|}{$\mathrm{TDD} \geq 77 \mathrm{mmHg}$} & - & - & - \\
\hline \multicolumn{2}{|l|}{$\mathrm{GDP} \geq 100 \mathrm{mg} / \mathrm{dL}$} & - & - & - \\
\hline \multicolumn{2}{|l|}{ Trigliserida $\geq 110 \mathrm{mg} / \mathrm{dL}$} & - & 3 & $15,8 \%$ \\
\hline \multicolumn{2}{|l|}{$\mathrm{HDL}<40 \mathrm{mg} / \mathrm{dL}$} & - & 4 & $21,1 \%$ \\
\hline \multicolumn{5}{|c|}{ Tabel 3. Kadar CRP pada Subyek } \\
\hline \multirow[t]{2}{*}{ Karakteristik } & \multicolumn{2}{|c|}{ Kadar CRP Tinggi } & \multicolumn{2}{|c|}{ Kadar CRP Rendah } \\
\hline & $\mathbf{N}$ & $\%$ & $\mathbf{N}$ & $\%$ \\
\hline \multicolumn{5}{|l|}{ Jenis kelamin } \\
\hline Laki-laki & 6 & $46,2 \%$ & 18 & $72 \%$ \\
\hline Perempuan & 7 & $53,8 \%$ & 7 & $28 \%$ \\
\hline \multicolumn{5}{|l|}{ Usia } \\
\hline 15 tahun & 6 & $46,2 \%$ & 6 & $24 \%$ \\
\hline 16 tahun & 5 & $38,5 \%$ & 11 & $44 \%$ \\
\hline 17 tahun & 2 & $15,4 \%$ & 8 & $32 \%$ \\
\hline
\end{tabular}

Tabel 3 menunjukkan bahwa subjek yang memiliki kadar CRP tinggi lebih sedikit dibandingkan dengan subjek yang memiliki kadar CRP rendah. Menurut usia, subjek dengan usia 15 tahun yang paling banyak memiliki kadar CRP tinggi. Subjek usia 16 tahun yang paling banyak memiliki kadar CRP rendah.

\section{Hubungan Densitas Energi dengan Faktor Risiko Sindrom Metabolik dan Kadar $C$ - Reactive Protein (CRP)}

Tabel 4 menunjukkan bahwa densitas energi makanan secara bermakna berhubungan dengan IMT dan lingkar pinggang $(\mathrm{p}<0,05)$ sedangkan dengan tekanan darah sistolik, tekanan darah diastolik, kadar GDP, kadar trigliserid dan HDL tidak ada hubungan ( $\mathrm{p}>0,05)$.

Tabel 4. Hubungan Densitas Energi dengan Faktor RisikoSindrom Metabolik

\begin{tabular}{lcc}
\hline Variabel & \multicolumn{2}{c}{ Densitas Energi } \\
\cline { 2 - 3 } & $\mathrm{r}$ & $\boldsymbol{p}$ \\
\hline IMT & 0,458 & $0,004^{*}$ \\
Lingkar pinggang & 0,506 & $0,001^{*}$ \\
Tekanan darah sistol & 0,166 & 0,320 \\
Tekanan darah diastol & 0,311 & 0,057 \\
Gula darah puasa & 0,203 & 0,222 \\
Trigliserid & 0,142 & 0,396 \\
HDL & $-0,113$ & 0,498 \\
\hline
\end{tabular}

Catatan: $* \mathrm{p}<0,05$

\section{Densitas Energi dan Lingkar Pinggang sebagai Faktor Risiko Peningkatan Kadar C-Reative Protein (CRP)}

Tabel 5. Hubungan Densitas Energi dan Lingkar Pinggang terhadap Kadar CRP

\begin{tabular}{lcc}
\hline Variabel & \multicolumn{2}{c}{ Kadar CRP } \\
\cline { 2 - 3 } & $\mathrm{r}$ & $\boldsymbol{p}$ \\
\hline Densitas energi & 0,240 & 0,430 \\
Lingkar pinggang & 0,433 & 0,139
\end{tabular}

Tabel 5 menunjukkan bahwa $(\mathrm{p}>0,05)$ densitas energi makanan dan lingkar pinggang tidak terdapat hubungan yang bermakna antara dengan kadar CRP. 
Tabel 6. Hubungan Densitas Energi dan Lingkar Pinggang terhadap Kadar CRP

\begin{tabular}{|c|c|c|c|c|c|}
\hline & \multicolumn{2}{|c|}{ Kadar CRP Tinggi } & \multicolumn{2}{|c|}{ Kadar CRP Normal } & \multirow[t]{2}{*}{$\mathbf{R P}$} \\
\hline & $\mathrm{N}$ & $\%$ & $\mathrm{~N}$ & $\%$ & \\
\hline \multicolumn{6}{|l|}{ Densitas energi } \\
\hline Tinggi & 9 & 69,2 & 21 & 84,0 & 0,6 \\
\hline Normal & 4 & 30,8 & 4 & 16,0 & \\
\hline \multicolumn{6}{|l|}{ Lingkar pinggang } \\
\hline Diatas median & 7 & 53,8 & 12 & 48,0 & 1,3 \\
\hline Dibawah median & 6 & 46,2 & 13 & 52,0 & \\
\hline
\end{tabular}

Tabel 6 menunjukkan bahwa subjek yang memiliki densitas energi tinggi lebih sedikit yang memiliki kadar CRP yang tinggi tapi lebih banyak yang memiliki kadar CRP normal. Subjek yang memiliki densitas energi normal memiliki jumlah yang sama antara yang memiliki kadar CRP tinggi maupun rendah. Subjek yang memiliki densitas energi tinggi lebih banyak yang memiliki kadar CRP tinggi daripada subjek dengan densitas energi normal.

Jumlah subjek yang memiliki lingkar pinggang diatas median lebih rendah yang memiliki kadar CRP tinggi tapi lebih banyak yang memiliki kadar CRP normal. Subjek yang memiliki lingkar pinggang dibawah median lebih sedikit yang memiliki kadar CRP tinggi daripada yang memiliki kadar CRP normal. Subjek dengan lingkar pinggang diatas median lebih banyak yang memiliki kadar CRP tinggi.

Dalam penelitian ini lingkar pinggang merupakan faktor risiko terhadap peningkatan kadar CRP. Densitas energi makanan tidak terbukti sebagai faktor risiko terhadap peningkatan kadar CRP.

\section{PEMBAHASAN}

Penelitian pendahuluan terhadap 835 subyek di SMA Negeri 2 Semarang menunjukkan prevalensi obesitas pada remaja usia 15-18 tahun sebesar 7,9\%. Prevalensi ini lebih tinggi dibandingkan dengan penelitian pada remaja di Kota Yogyakarta pada tahun 2006 yang menunjukkan prevalensi obesitas sebesar 4,9\%. Namun, prevalensi ini lebih rendah dibandingkan dengan penelitian yang dilakukan pada tahun 2005 di SMP Domenico Savio Semarang yang menunjukkan prevalensi obesitas sebesar $17,4 \% .^{17}$ Prevalensi obesitas pada penelitian yang dilakukan di SMP Domenico Savio dipengaruhi oleh karakteristik subyek pada penelitian ini yang sebagian besar remaja dengan tingkat sosial ekonomi yang tinggi sehingga mempengaruhi pola makan dan gaya hidup. Siswa SMA Negeri 2 Semarang dipilih dalam penelitian ini karena sebagian besar memiliki tingkat ekonomi menengah dan merata. Hal ini dapat dilihat dari siswa SMA Negeri 2 Semarang menggunakan transportasi seperti angkutan umum dan sepeda motor untuk berangkat sekolah.

Obesitas sentral yang terjadi pada remaja dipengaruhi oleh pola hidup seperti kebiasaan makan dan aktivitas fisik. Pemilihan makanan pada remaja tidak berdasarkan pada kandungan gizi tetapi pada status sosial, sehingga remaja cenderung memilih makanan cepat saji (fast food). ${ }^{18}$ Beberapa faktor penyebab obesitas pada remaja antara lain asupan makanan berlebih yang berasal dari jenis makanan olahan instan, soft drink, makanan cepat saji seperti burger, pizza, hot dog, kurang konsumsi buah dan sayur serta aktivitas fisik yang kurang. ${ }^{19}$ Makanan padat energi adalah makanan dengan densitas energi yang tinggi, biasanya tinggi kadungan karbohidrat sederhana, gula dan lemak, maka cenderung lebih lezat dan gurih sehingga lebih disukai oleh remaja. $^{7}$

Pemilihan makanan pada remaja sangat dipengaruhi oleh faktor lingkungan dan harga diri. Remaja cenderung mengkonsumsi makanan yang tinggi kalori seperti kentang goreng, ayam goreng serta makanan siap saji lainnya. Asupan makanan yang berlebih akan menimbulkan keseimbangan energi positif yang dapat menyebabkan terjadinya obesitas. Pada penelitian ini ditemukan bahwa densitas energi mempunyai hubungan yang bermakna $(p<0,05)$ dengan lingkar pinggang dan IMT. Semakin tinggi asupan dengan densitas energi tinggi yang dikonsumsi maka semakin besar lingkar pinggang dan IMT.

Lingkar pinggang merupakan salah satu faktor risiko sindrom metabolik. Prevalensi sindrom metabolik pada penelitian ini sebesar $15,2 \%$ pada subyek obesitas. Pada penelitian ini prevalensi sindrom metabolik hanya ditemukan pada subyek laki-laki $(21,27 \%)$, sedangkan semua subyek perempuan termasuk dalam pra sindrom metabolik. Hal ini menunjukkan bahwa prevalensi sindrom metabolik lebih tinggi pada remaja laki- 
laki dibandingkan dengan remaja perempuan. Hasil ini sebanding dengan penelitian yang dilakukan pada tahun 2005 di Amerika Serikat dengan prevalensi sindrom metabolik pada remaja laki-laki sebesar 6,3\%, sedangkan prevalensi sindrom metabolik pada perempuan sebesar $4,1 \%$. Prevalensi sindrom metabolik lebih tinggi pada remaja laki-laki karena laki-laki lebih rentan terhadap obesitas sentral. ${ }^{21}$ Laki-laki lebih rentan terhadap obesitas sentral karena laki-laki tidak memiliki hormon estrogen. Hormon estrogen dapat mencegah penyimpanan lemak di viseral. ${ }^{22}$

Pada penelitian ini faktor risiko sindrom metabolik yang berdasarkan NCEP ATP III adalah lingkar pinggang (100\%), hipokolesterol HDL (90\%), hipertensi (80\%), dan hipertrigliserida $(60 \%)$. Hasil penelitian ini sebanding dengan penelitian pada remaja tahun 2012 di Brazil yang menunjukkan bahwa faktor risiko sindrom metabolik seperti obesitas sentral (55\%), hipokolesterol HDL (35,5\%), hipertensi $(21 \%)$, hipertrigliserida $(18,5 \%)$, dan hiperglikemi $(2 \%)$. Pada penelitian ini semua subyek mengalami obesitas sentral $(100 \%)$ karena obesitas sentral merupakan salah satu faktor risiko sindrom metabolik, sehingga saat skrining semua siswa obesitas sentral termasuk dalam subyek penelitian.

Lingkar pinggang merupakan faktor risiko sindrom metabolik yang paling tinggi. Obesitas sentral lebih menunjukkan adanya inflamasi, karena penumpukan jaringan adiposa pada perut dapat meningkatkan konsentrasi proinflamatori sitokin. Jaringan lemak viseral dapat meningkatkan kadar pro-inflamatori sitokin untuk memproduksi inflamatori sitokin. ${ }^{7}$ Peningkatan lemak viseral adalah faktor risiko penyakit jantung koroner, dislipidemia, hipertensi, stroke, diabetes tipe 2 dan sindrom metabolik. ${ }^{21}$ Lingkar pinggang lebih baik digunakan untuk melihat risiko kesehatan pada dewasa. Lingkar pinggang lebih sensitif dan spesifik untuk pengukuran lemak tubuh atas pada anak-anak dan remaja, sehingga lebih mudah mengidentifikasi kelebihan berat badan dan obesitas yang terjadi pada remaja. ${ }^{23}$

Jaringan lemak viseral dapat meningkatkan dan merubah kadar Tumor Necrosis Factor (TNF- $\alpha$ ) untuk memproduksi inflamatory sitokin. ${ }^{21}$ Produksi $C$-reactive protein (CRP) induksi oleh Interleukin-6 (IL-6) dan diregulasi oleh TNF- $\alpha$. Nilai CRP yang tinggi dapat menunjukkan adanya induksi sitokin yang menggambarkan proses proinflamasi. ${ }^{12}$ Sindrom metabolik merupakan sekumpulan faktor risiko penyakit kardiovaskuler. Atherosklerosis merupakan suatu proses inflamasi, kadar CRP yang tinggi menunjukkan aktivasi inflamasi yang terjadi yang merupakan karakteristik dari penyakit arteri koroner, sehingga CRP merupakan marker inflamasi sebagai prediktor yang potensial terhadap kejadian penyakit jantung koroner.

Semua subyek dalam penelitian memiliki lingkar pinggang yang memenuhi kriteria sindrom metabolik, sehingga dilakukan pengkategorian berdasarkan nilai median $>101,25 \mathrm{~cm}$ dan $<101,25$ $\mathrm{cm}$ untuk melihat perbedaan lingkar pinggang terhadap kelompok kadar CRP tinggi dan kadar CRP rendah. Dalam penelitian ini lingkar pinggang terbukti merupakan faktor risiko terhadap peningkatan kadar CRP. Densitas energi makanan tidak terbukti sebagai faktor risiko terhadap peningkatan kadar CRP. Kelebihan energi semakin tinggi maka akan terjadi penumpukan lemak dijaringan adiposa. Jaringan adiposa dapat meningkatkan produksi proinflamatori seperti IL-6 dan TNF- $\alpha$ yang akan membantu membenahi ketidakseimbangan metabolisme yang diakibatkan oleh kelebihan asupan makanan. IL-6 dan TNF- $\alpha$ dapat menginduksi CRP, tetapi jika metabolisme tubuh sudah membaik dengan adanya IL- 6 dan TNF- $\alpha$ maka CRP tidak diproduksi. ${ }^{24}$

\section{SIMPULAN}

Prevalensi obesitas remaja di SMA Negeri 2 Semarang adalah sebesar 7,9\%. Prevalensi sindrom metabolik pada remaja obesitas adalah sebesar 15,2\%. Dalam penelitian ini lingkar pinggang terbukti merupakan faktor risiko terhadap peningkatan kadar CRP. Densitas energi makanan tidak terbukti sebagai faktor risiko terhadap peningkatan kadar CRP.

\section{SARAN}

Lingkar pinggang yang besar menunjukkan terjadinya sindrom metabolik untuk menjaga agar lingkar pinggang tetap sesuai maka perlu melakukan pola hidup yang sehat seperti memperbanyak konsumsi sayur dan buah, membatasi asupan makanan densitas energi tinggi serta melakukan aktivitas fisik dengan cukup.

\section{DAFTAR PUSTAKA}

1. Rohman MS. Patogenesis dan Terapi Sindroma Metabolik. Jurnal Kardiologi Indonesia J Kardiol Ind 2007; 28:160-168 ISSN 0126/3773

2. Cameron AJ, Shaw JE, Zimmet. The metabolic Syndrome: Prevalence in Worldwide Populations. Endocrinol Metab Clin N Am 2004; 33:351-75 
3. Wen-harn pan. Epidemiology of Metabolic Syndrome in Asia. Asia Pac J Clin Nutr 2008; 17(s1):37-42

4. Cook S. Prevalence of a Metabolic Syndrome Phenotype in Adolecents. Arch Pediatr Adolesc Med. 2003; 157: 821-7

5. Parlindungan F. Sindrom Metabolik dan Penyakit Kardiovaskuler. Divisi Kardiologi. Departemen Ilmu Penyakit Dalam. Fakultas Kedokteran. Universitas Sumatra Utara.

6. Banowati L. Risiko Konsumsi Western Fast Food dan Kebiasaan Tidak Makan Pagi terhadap Obesitas Remaja Studi di SMAN 1 Cirebon. Media Medika Indonesiana. Fakultas Kedokteran Universitas Diponegoro dan Ikatan Dokter Indonesia wilayah Jawa Tengah. 2011

7. Kant AK, graubard BI. Energy Density is Associated with Energy Intake and Weight. Int J Obes Relat Metab Disord 29:950-956, 2005

8. Badan Litbang Kesehatan Departemen Kesehatan RI. Laporan Hasil Riset Kesehatan Dasar (RISKESDAS) Nasional 2007. Jakarta

9. Rutter MK. Epidemiologi Evidence Against a Role for C-Reactive Protein Causing Leptin Resistence. European Journal Of Endocrinology (2013) 168 101-106

10. Rachmah Q. Perbedaan Proporsi Sindrom Metabolik pada Guru Sekolah Dasar Obes Sentral dan Non-Obes Sentral Berdasarkan Lingkar Perut. Bimgi volume 2 no.1. 2013

11. Kartika C. Adiponectin, Total Anti-Oxidant Status, and High Sensitivity C-Reactive Protein in Indonesian Men with Metabolic Syndrome. Vol.18, no. 4, 2009

12. Soetiarto F. Hubungan Diabetes Mellitus dengan Obesitas Berdasarkan Indeks Massa Tubuh dan Lingkar Pinggang Data RISKESDAS 2007. Buletin Penelitian Kesehatan vol. 38, no. 1, 2010: $36-42$

13. Wanberg J. Inflammatory Proteins are Related to Total and Abdominal Adiposity In A Healthy Adolescent Population: THE AVENA STUDY. Am J Clin Nutr 2006.

14. Mahan IK, Stump S, Raymond J. Krause's Food and the Nutrition Care Process. Edition 13.

15. Boyd GS. Effect of Obesity and High Blood Pressure on Plasma Lipid Levels in Children Obesity. Pediatric. 2005; 116:442-6

16. Esmaillzadeh A. Fruit And Vegetable Intake, CReactive Protein,And The Metabolic Syndrome. AM J Clin Nutr 2006;84:1489-97. Printed in usa. (C) 2006 American Society for Nutrition

17. Mexitalia M, Utari A, Sakundarno M, Yamauchi T, Subagio HW, Soemantri A. Sindrom Metabolik pada Remaja Obesitas. Media Medika Indonesiana. Fakultas Kedokteran Universitas Diponegoro. Ikatan Dokter Indonesia Wilayah Jawa Tengah. 2009
18. Sargowo D, Andarini S. The Relationship Between Food Intake And Adolescent Metabolic Syndrome. Jurnal Kardiologi Indonesia . vol. 32, no. 1 . Januari - Maret 2011

19. Sartika RAD. Faktor Risiko Obesitas pada Anak 515 Tahun di Indonesia. Departemen Gizi Kesehatan Masyarakat. Fakultas Kesehatan Masyarakat. Universitas Indonesia. MAKARA, Kesehatan, Vol. 15, No. 1. 2011

20. Ashima KK. Consumtion Of Energy-Dense, Nutrient-Poor Foods By Adult Americans: Nutritional And Health Implication. The Third National Health And Nutrition Examination Survey, 1988-1994. The American Journal Of Clinical Nutrition 2000; 72:929-36

21. Cartier A. Sex Differences in Inflammatory Markers: What IsThe Contribution of Visceral Adiposity. The American Journal Of Clinical Nutrition 2009

22. Barasi ME. 2009. Nutrition at A Glance. Jakarta: Erlangga

23. Katzmarzyk P. Body Mass Index, Waist Circumference And Clustering Of Cardiovascular Disease Risk Factors In A Biracial Sample Of Children And Adolescents. American Academic Of Pediatric. 2004

24. Baratawidjaja KG, Rengganis I. 2009.Imunologi Dasar.Jakarta: Fakultas Kedokteran Universitas Indonesia 